\title{
Commodity Chemicals and Fuels from Biomass: Thermodynamic Properties of Levoglucosan Derivatives
}

Irina V. Andreeva, ${ }^{a}$ Aleksey A. Pimerzin, ${ }^{b}$ Vladimir V. Turovtsev, ${ }^{c}$ Shuai Qian, ${ }^{d}$ Jason E. Bara, ${ }^{d}$ Des Richardson, Sergey P. Verevkin. ${ }^{a, b, *}$

a Department of Physical Chemistry and Faculty of Interdisciplinary Research, Competence Centre CALOR, University of Rostock, 18059 Rostock, Germany

${ }^{b}$ Chemical Department, Samara State Technical University, 443100 Samara, Russia

${ }^{c}$ Department of Physics, Tver State Medical University, 170100 Tver, Russia

${ }^{d}$ Department of Chemical \& Biological Engineering, University of Alabama, Tuscaloosa, AL, 35487-0203, USA

${ }^{e}$ Norske Skog ASA, NO-0213 Oslo, Norway

Corresponding author's email address: sergey.verevkin@uni-rostock.de

\section{Cyrene density measurement}

Density measurements for Cyrene was conducted on a Mettler Toledo DM45 DeltaRange density meter at $101 \mathrm{kPa}$ within the temperature range of $293.15-353.15 \mathrm{~K}$ (temperature error: $\pm 0.05 \mathrm{~K}$ ) controlled automatically by the device with increments of $10.00 \mathrm{~K}$. Calibrations were conducted using water standards provided by the manufacturer. The sample cell was cleaned before sample injection and after completion of measurements via purging the sample from the chamber, followed by injection of acetone to rinse the chamber and finally injecting air until dry.

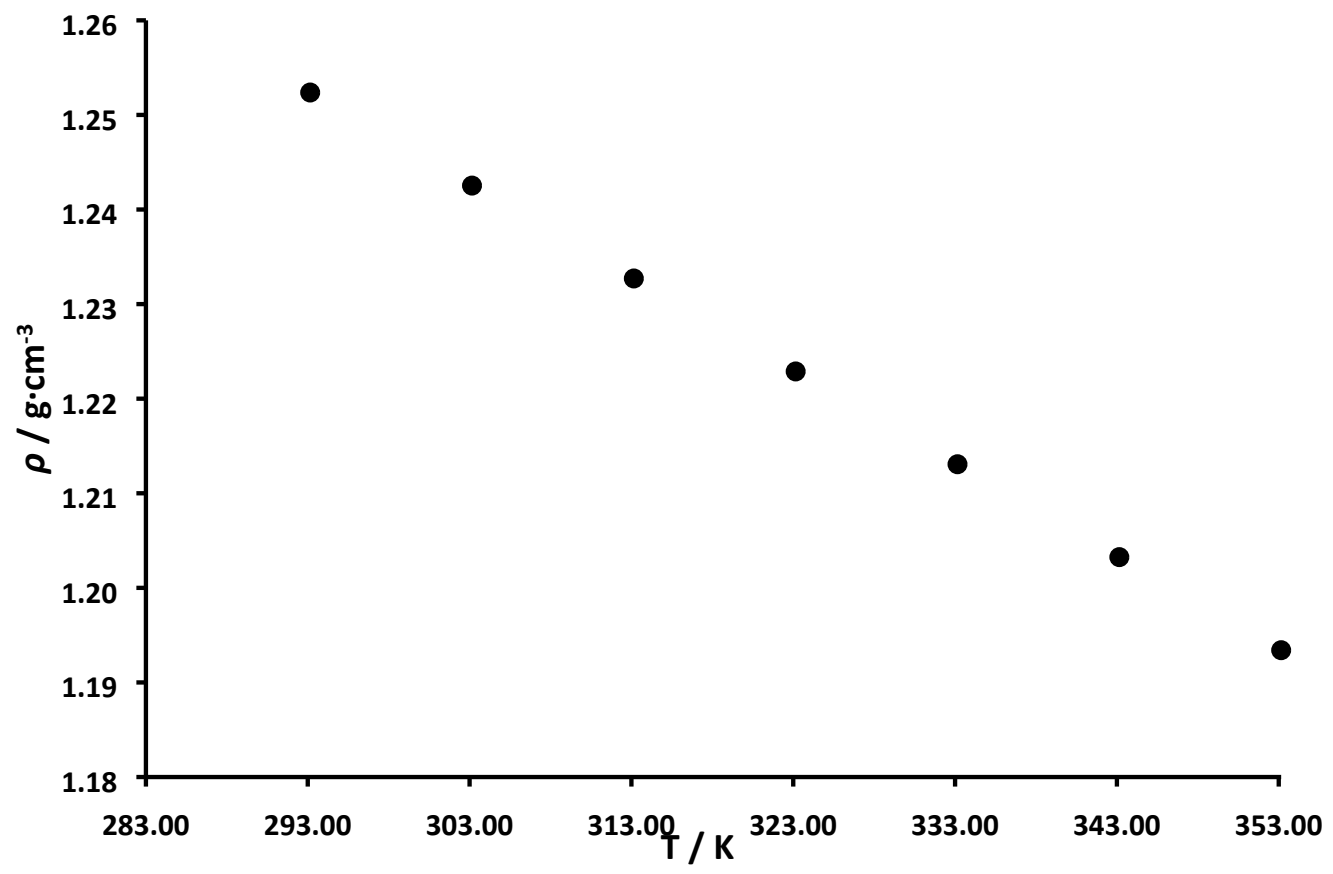

Figure S1: Temperature dependence of density of Cyrene and regression equation. 


\section{Cyrene viscosity measurement}

Dynamic viscosities of Cyrene were measured on a Brookfield DV-II + Pro viscometer using the 'ULA' spindle and jacketed sample cell at $101 \mathrm{kPa}$ and within the temperature range of 293.15 $353.15 \mathrm{~K}$ (temperature error: $\pm 0.01 \mathrm{~K}$ ) controlled automatically by Brookfield TC-602P circulating bath with increments of $5.00 \mathrm{~K}$ or $10.00 \mathrm{~K}$ through programming. The sample cell was washed with acetone rinsing followed by air drying before and after each measurement.

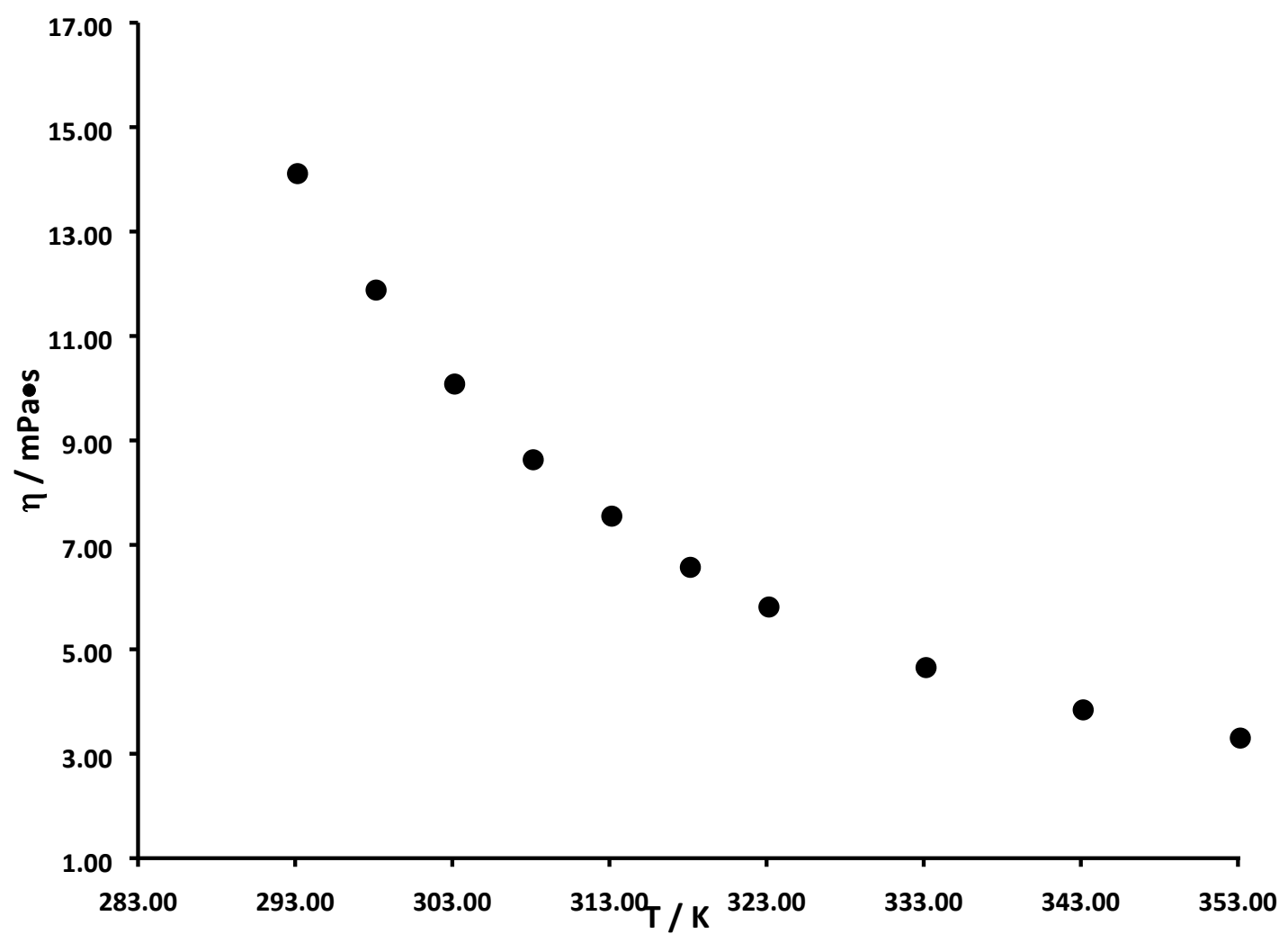

Figure S2: Temperature dependence of viscosity of Cyrene and regression equation. 


\section{Table S1}

Formula, density $\rho(T=293 \mathrm{~K})$ and massic heat capacity $c_{\mathrm{p}}(T=298.15 \mathrm{~K})$ of the materials used in the present study

\begin{tabular}{lclcc}
\hline Compounds & $\begin{array}{c}\text { Water content } \\
\text { a }\end{array}$ & \multicolumn{1}{c}{ Formula } & \multicolumn{1}{c}{$\rho$} & $c_{\mathrm{p}}{ }^{\mathrm{b}}$ \\
\cline { 4 - 5 } & $\mathrm{ppm}$ & & $\mathrm{g} \cdot \mathrm{cm}^{-3}$ & $\mathrm{~J} \cdot \mathrm{K}^{-1} \mathrm{~g}^{-1}$ \\
\hline cyrene & 6858 & $\mathrm{C}_{6} \mathrm{H}_{8} \mathrm{O}_{3}$ & $1.30[1]$ & 1.53 \\
levoglucosenone & 2958 & $\mathrm{C}_{6} \mathrm{H}_{6} \mathrm{O}_{3}$ & $1.25[1]$ & 1.61 \\
polyethylene $^{\mathrm{c}}$ & & $\mathrm{CH}_{1.93}$ & $0.92[2]$ & 2.53 \\
cotton $^{\mathrm{c}}$ & & $\mathrm{CH}_{1.774} \mathrm{O}_{0.887}$ & $1.50[2]$ & 1.67 \\
\hline
\end{tabular}

a Determined by the Karl-Fisher titration in this work and used for mass corrections for combustion experiments.

${ }^{b}$ Measured in this work (see main text).

${ }^{c}$ Data for density, specific heat capacity, and expansion coefficients of auxiliary materials are from our previous work [2]: specific energy of combustion $\Delta_{\mathrm{c}} u^{\circ}$ (cotton) $=-16945.2 \mathrm{~J} \cdot \mathrm{g}^{-1} ; u\left(\Delta_{\mathrm{c}} u^{\circ}\right)=4.2$ $\mathrm{J} \cdot \mathrm{g}^{-1}$. We used the polyethylene ampoules as the container for liquids, as well as an auxiliary material in order to ensure a completeness of combustion. The specific energies of combustion $\Delta_{\mathrm{c}} u^{\circ}$ (polyethylene) $=-46416.5 \mathrm{~J} \cdot \mathrm{g}^{-1} ; u\left(\Delta_{\mathrm{c}} u^{\circ}\right)=4.6 \mathrm{~J} \cdot \mathrm{g}^{-1}$ were derived from ten combustion experiments performed in our lab. The standard uncertainties are reported for the specific energies of combustion.

\section{Heat capacity measurements [3]}

The experimental protocol of heat capacity determination included the three equal iterations with an empty pan, a reference sample of sapphire and a sample of each compound being researched. For each iteration there was an equal thermal program of study; for all steps of each measurement the same pan was used. In each iteration the sample was heated with the step of $50 \mathrm{~K}$ at heating rate of $10 \mathrm{~K} \cdot \mathrm{min}^{-1}$. Before and after each scanning step sample was kept isothermally for two minutes. Inside each iteration the temperature range was divided into intervals of $50 \mathrm{~K}$ to heat samples and between them there was a shift of $25 \mathrm{~K}$. Each step for all iterations was repeated 4 times.

The heat capacity was derived with the Perkin Elmer software. The heat capacity determination technique was tested with a reference sample of benzoic acid by Parr Instrument Company. In the chosen temperature ranges the experimental values agreed with the reference values within $\pm 1 \%$. The expanded uncertainty $(\mathrm{k}=2)$ for the heat capacity measured by this method was estimated to be $0.02 \times C_{\mathrm{p}, \mathrm{m}}^{\mathrm{o}}$. The primary results are collected in Table $\mathrm{S} 2$. 


\section{Table S2}

Compilation of data on molar heat capacities $C_{\mathrm{p}, \mathrm{m}}^{\mathrm{o}}(\mathrm{liq})$ (in $\mathrm{J} \cdot \mathrm{K}^{-1} \cdot \mathrm{mol}^{-1}$ ) at $T=298.15 \mathrm{~K}$ for dehydrolevoglucosenone and levoglucosenone

\begin{tabular}{|c|c|c|c|c|c|}
\hline \multicolumn{3}{|c|}{ dehydrolevoglucosenone } & \multicolumn{3}{|c|}{ levoglucosenone } \\
\hline$T, \mathrm{~K}$ & $C_{\mathrm{p}, \mathrm{m}}^{\mathrm{o}}(\mathrm{liq})$ & $T, \mathrm{~K}$ & $C_{\mathrm{p}, \mathrm{m}}^{\mathrm{o}}(\mathrm{liq})$ & $T, \mathrm{~K}$ & $C_{\mathrm{p}, \mathrm{m}}^{\mathrm{o}}(\mathrm{liq})$ \\
\hline 231 & 179.8 & 306.5 & 205.5 & 341.5 & 219.6 \\
\hline 234 & 180.2 & 307.5 & 205.9 & 342.5 & 219.8 \\
\hline 239 & 180.9 & 308.5 & 206.4 & 343.5 & 220.0 \\
\hline 244 & 181.6 & 309.5 & 207.0 & 344.5 & 220.3 \\
\hline 249 & 182.5 & 310.5 & 207.5 & 345.5 & 220.6 \\
\hline 254 & 183.4 & 311.5 & 208.0 & 346.5 & 220.9 \\
\hline 259 & 184.1 & 312.5 & 208.6 & 347.5 & 221.2 \\
\hline 264 & 185.1 & 313.5 & 209.1 & 348.5 & 221.5 \\
\hline 269 & 186.2 & 314.5 & 209.6 & 349.5 & 221.8 \\
\hline 274 & 187.1 & 315.5 & 210.1 & 350.5 & 222.1 \\
\hline 279 & 187.9 & 316.5 & 210.6 & 351.5 & 222.4 \\
\hline 285 & 189.5 & 317.5 & 211.1 & 352.5 & 222.7 \\
\hline 289 & 190.7 & 318.5 & 211.6 & 353.5 & 223.1 \\
\hline 294 & 191.9 & 319.5 & 212.1 & 354.5 & 223.4 \\
\hline 299 & 193.2 & 320.5 & 212.6 & 355.5 & 223.7 \\
\hline 304 & 194.8 & 321.5 & 213.1 & 356.5 & 224.0 \\
\hline 309 & 196.1 & 322.5 & 213.5 & 357.5 & 224.3 \\
\hline 314 & 197.4 & 323.5 & 214.0 & 358.5 & 224.7 \\
\hline 319 & 198.8 & 324.5 & 214.4 & 359.5 & 225.0 \\
\hline 323 & 200.0 & 325.5 & 214.8 & 360.5 & 225.4 \\
\hline & & 326.5 & 215.2 & 361.5 & 225.7 \\
\hline & & 327.5 & 215.6 & 362.5 & 226.0 \\
\hline & & 328.5 & 216.0 & 363.5 & 226.3 \\
\hline & & 329.5 & 216.3 & 364.5 & 226.6 \\
\hline & & 330.5 & 216.6 & 365.5 & 226.9 \\
\hline & & 331.5 & 216.9 & 366.5 & 227.2 \\
\hline & & 332.5 & 217.2 & 367.5 & 227.6 \\
\hline & & 333.5 & 217.5 & 368.5 & 227.9 \\
\hline & & 334.5 & 217.8 & 369.5 & 228.2 \\
\hline & & 335.5 & 218.1 & 370.5 & 228.5 \\
\hline & & 336.5 & 218.3 & 371.5 & 228.8 \\
\hline & & 337.5 & 218.6 & 372.5 & 229.1 \\
\hline & & 338.5 & 218.8 & 373.5 & 229.3 \\
\hline & & 339.5 & 219.1 & 374.5 & 229.7 \\
\hline & & 340.5 & 219.3 & 375.5 & 230.0 \\
\hline
\end{tabular}




\section{Vapor pressure measurements. Transpiration method [4,5]}

Absolute vapour pressures were measured using the transpiration method [4,5]. The main idea of this method is to saturate the gas stream flowing over the sample and to determine the amount of compound transferred by the gas within a given time. Approximately 0.5 to $0.8 \mathrm{~g}$ of the sample is mixed with glass beads (diameter $1 \mathrm{~mm}$ ) and placed in the thermostatted U-shaped saturator. The glass beads are needed to enlarge the contact area between gas and sample. A stream of nitrogen at a well-defined flow rate was passed through the saturator at constant temperature $( \pm 0.1 \mathrm{~K})$, and the transported material was collected in a cold trap. The amount of the condensed substance was determined by GC. The saturation vapour pressure $p_{i}$ at each temperature $T_{i}$ was calculated from the amount of condensate collected within a definite period of time:

$$
p_{i}=m_{i} \cdot R \cdot T_{\mathrm{a}} / V \cdot M_{i} ; \quad V=\left(n_{\mathrm{N} 2}+n_{i}\right) \cdot R \cdot T_{\mathrm{a}} / P_{\mathrm{a}}
$$

where $V$ is the volume of the gas phase consisting of the $n_{\mathrm{N} 2}$ moles of the carrier gas and $n_{i}$ mole of gaseous compound under study (with the molar mass $M_{i}$ ) at the atmospheric pressure $P_{\mathrm{a}}$ and the ambient temperature $T_{\mathrm{a}}$. The volume of the carrier gas $V_{\mathrm{N} 2}$ was determined by the digital flow rate sensor from integration with a microcontroller. We used the Honeywell S\&C - HAFBLF0200C2AX5 digital flow rate sensor with uncertainty at the level of $2.5 \%$. The flow rate of the nitrogen stream was also controlled by using a soap bubble flow meter (HP soap film flowmeter (model 0101-0113)) and optimized in order to reach the saturation equilibrium of the transporting gas at each temperature under study. The volume of the carrier gas $V_{\mathrm{N} 2}$ was readied from the digital flow rate sensor. The amount of the compound under investigation $n_{i}$ in the carrier gas was estimated at each temperature using the ideal gas law.

Before starting the vapour pressure measurements, the sample was first pre-conditioned at 310-320 K (within about one hour) in order to remove possible traces of water. The saturator was then kept at $310-315 \mathrm{~K}$ (to remove possible traces of volatile compounds). In order to assure the competition of pre-conditioning at the selected temperature, three samples were taken during the sample flashing at and analysed by the GC. A constant vapour pressure at this temperature indicated that the transpiration experiments could begin. GC analysis of the transported material did not reveal any additional contamination. The absence of impurities and decomposition products was re-checked by GC analysis of the saturator content at the end of the entire series of experiments.

The experimental vapour pressures $p_{i}$ temperature dependences measured for the vanillins (see Table 1) with help of the transpiration method were fitted with the following equation $[4,5]$ :

$$
R \times \ln \left(p_{i} / p_{\text {ref }}\right)=a+\frac{b}{T}+\Delta \mathrm{P} C_{\mathrm{p}, \mathrm{m}}^{\mathrm{o}} \times \ln \left(\frac{T}{T_{0}}\right)
$$

where $\Delta_{\mathrm{P}}^{\mathrm{g}} C_{\mathrm{p}, \mathrm{m}}^{\mathrm{o}}$ is the difference of the molar heat capacities of the gas and the liquid phases respectively, $a$ and $b$ are adjustable parameters, $R=8.31446 \mathrm{~J} \cdot \mathrm{K}^{-1} \cdot \mathrm{mol}^{-1}$ is the molar gas constant, and the reference pressure $p_{\text {ref }}=1 \mathrm{~Pa}$. The arbitrary temperature $T_{0}$ given in Eq. (S1) was chosen to be $T_{0}=298.15 \mathrm{~K}$. 


\section{Table S3}

Compilation of Solid-Solid and Solid-Liquid Phase Transitions Thermodynamics of Levoglucosan $\left(\text { in } \mathrm{kJ} \cdot \mathrm{mol}^{-1}\right)^{\mathrm{a}}$

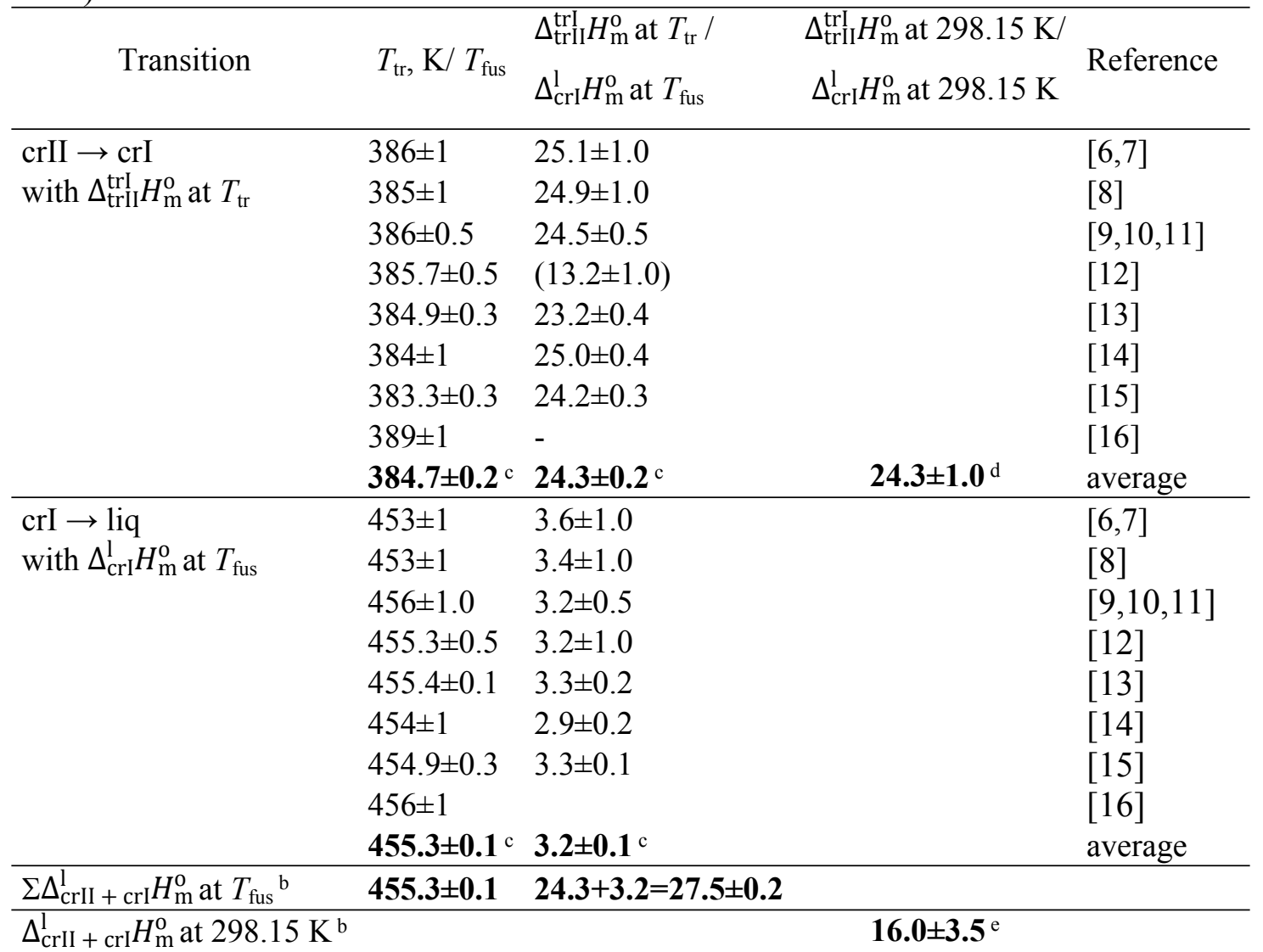

${ }^{a}$ Uncertainties are presented as expanded uncertainties ( 0.95 level of confidence with $\left.\mathrm{k}=2\right)$.

$\mathrm{b}$ The sum of the solid-solid and solid-liquid phase transitions, referenced to the temperature of fusion.

${ }^{c}$ Weighted average value (with the experimental uncertainty used as the weighing factor). Values highlighted in bold were used for thermochemical calculations. Values in parenthesis seem to be in error.

d Was adjusted to $T=298.15 \mathrm{~K}$ according to the Kirchhoff's Law:

$\Delta_{\mathrm{crII}}^{\mathrm{crl}} H_{\mathrm{m}}^{\mathrm{o}}(298.15 \mathrm{~K}) /\left(\mathrm{J} \cdot \mathrm{mol}^{-1}\right)=\Delta_{\mathrm{crII}}^{\mathrm{cr}} H_{\mathrm{m}}^{\mathrm{o}}\left(T_{\mathrm{fus}} / \mathrm{K}\right)-\left[C_{\mathrm{p}, \mathrm{m}}^{\mathrm{o}}(\mathrm{crII})-C_{\mathrm{p}, \mathrm{m}}^{\mathrm{o}}(\mathrm{crI})\right] \times\left[\left(T_{\mathrm{tr}} / \mathrm{K}\right)-298.15 \mathrm{~K}\right]$ with assumption that $\left.C_{\mathrm{p}, \mathrm{m}}^{\mathrm{o}}(\mathrm{crII}) \approx C_{\mathrm{p}, \mathrm{m}}^{\mathrm{o}}(\mathrm{crI})\right]$, and $C_{\mathrm{p}, \mathrm{m}}^{\mathrm{o}}(\mathrm{crII})$ was taken from Table 3 . The uncertainty in the temperature adjustment of the $\Delta_{\mathrm{crII}}^{\mathrm{cr}} H_{\mathrm{m}}^{\mathrm{o}}$ from $T_{\text {tr }}$ to the reference temperature was assessed to be at the level of $1 \mathrm{~kJ} \cdot \mathrm{mol}^{-1}$.

e The experimental enthalpy of fusion $\Delta_{\mathrm{cr}}^{1} H_{\mathrm{m}}^{\mathrm{o}}$ (calculated as the sum of solid-solid and solid-liquid phase transitions and referenced to $T_{\text {fus }}$ ) was adjusted to $T=298.15 \mathrm{~K}$ with help of the equation [17]: $\Delta_{\mathrm{cr}}^{\mathrm{l}} H_{\mathrm{m}}^{\mathrm{o}}(298.15 \mathrm{~K}) /\left(\mathrm{J} \cdot \mathrm{mol}^{-1}\right)=\Delta_{\mathrm{cr}}^{\mathrm{l}} H_{\mathrm{m}}^{\mathrm{o}}\left(T_{\mathrm{fus}} / \mathrm{K}\right)-\left(\Delta_{\mathrm{cr}}^{\mathrm{g}} C_{\mathrm{p}, \mathrm{m}}^{\mathrm{o}}-\Delta_{\mathrm{P}}^{\mathrm{s}} C_{\mathrm{p}, \mathrm{m}}^{\mathrm{o}}\right) \times\left[\left(T_{\text {fus }} / \mathrm{K}\right)-298.15 \mathrm{~K}\right]$

where $\Delta_{\mathrm{cr}}^{\mathrm{g}} C_{\mathrm{p}, \mathrm{m}}^{\mathrm{o}}$ and $\Delta_{\mathrm{P}}^{\mathrm{g}} C_{\mathrm{p}, \mathrm{m}}^{\mathrm{o}}$ were taken from Table 3. Uncertainties in the temperature adjustment of the sum of the phase enthalpies from $T_{\text {fus }}$ to the reference temperature are estimated to account with $30 \%$ to the total adjustment [18]. 


\section{Table S4}

Evaluation of the standard molar enthalpies of vaporization, $\Delta \Delta_{\mathrm{P}}^{\mathrm{g}} H_{\mathrm{m}}^{\mathrm{o}}$, of cyclo-alkanes, cyclo-alkenes, cyclo-alkanones, and cyclo-alkenones available in the literature.

\begin{tabular}{lllll}
\hline Compound & $\mathrm{M}^{\mathrm{a}}$ & $T$-range & $\Delta_{\mathrm{\rho}}^{\mathrm{g}} H_{\mathrm{m}}^{\mathrm{o}}\left(T_{\mathrm{av}}\right)$ & $\Delta_{\mathrm{\rho}}^{\mathrm{g}} H_{\mathrm{m}}^{\mathrm{o}}(298.15 \mathrm{~K})^{\mathrm{b}}$ \\
\hline cyclopentene & & $\mathrm{K}$ & $\mathrm{kJ} \cdot \mathrm{mol}^{-1}$ & $\mathrm{~kJ} \cdot \mathrm{mol}^{-1}$ \\
\hline cycloheptene & $\mathrm{E}$ & $284.5-318.2$ & $28.5 \pm 0.1$ & $28.6 \pm 0.2[19]$ \\
\hline 2-cyclohexene-1-one & $\mathrm{S}$ & $251.7-312.2$ & $36.4 \pm 0.2$ & $37.6 \pm 0.3[20]$ \\
& $\mathrm{E}$ & $334.8-445.5$ & $43.8 \pm 0.1$ & $47.9 \pm 0.5[21]$ \\
& $\mathrm{E}$ & $350.4-445.0$ & $43.9 \pm 0.1$ & $48.0 \pm 0.5[22]$ \\
\hline cycloheptanone & & & & $\mathbf{4 7 . 9} \pm \mathbf{0 . 1}$ \\
\hline cyclooctanone & $\mathrm{S}$ & $313-383$ & $47.1 \pm 0.6$ & $50.1 \pm 0.7[23]$ \\
& $\mathrm{E}$ & $373.7-464.6$ & $43.5 \pm 0.1$ & $50.7 \pm 0.6[24]$ \\
& $\mathrm{CGC}$ & 298.15 & & $51.5 \pm 0.5[5]$ \\
& & & & $\mathbf{5 0 . 9} \pm \mathbf{0 . 3}$ \\
\hline & $\mathrm{S}$ & $323-403$ & $49.6 \pm 0.6$ & $54.1 \pm 0.7[23]$ \\
& $\mathrm{E}$ & $394.9-484.1$ & $45.6 \pm 0.1$ & $54.0 \pm 0.7[24]$ \\
& $\mathrm{CGC}$ & 298.15 & & $54.1 \pm 0.5[25]$ \\
& & & & $\mathbf{5 4 . 3} \pm \mathbf{0 . 3}$ \\
\hline
\end{tabular}

a Techniques: $\mathrm{S}=$ static method; $\mathrm{E}=$ ebulliometry; $\mathrm{CGC}=$ correlation gas-chromatographic method. $\mathrm{b}$ The primary vapor pressures available in the literature were approximated by Eq. (S1) and vaporization enthalpies at $T=298.15 \mathrm{~K}$ were derived according to equation:

$$
\Delta_{\mathrm{P}}^{\mathrm{g}} H_{m}^{\mathrm{o}}(298.15 \mathrm{~K})=-b+\Delta_{\mathrm{P}}^{\mathrm{g}} C_{p, m}^{\mathrm{o}} \times 298.15 \mathrm{~K}
$$

with the $\Delta_{\mathrm{P}}^{\mathrm{g}} C_{p, m}^{\mathrm{o}}-$ values from Table $\mathrm{S} 5$. Uncertainties of the vaporization enthalpies are expressed as the standard uncertainties $(0.68$ level of confidence, $\mathrm{k}=1)$. They include uncertainties from the experimental conditions and the fitting equation, vapour pressures, and uncertainties from adjustment of vaporization enthalpies to the reference temperature $T=298.15 \mathrm{~K}[26,27]$.

${ }^{\mathrm{c}}$ The primary vapor pressures from [21] and [22] were approximated by Eq. 8 and vaporization enthalpies at $T=298.15 \mathrm{~K}$ were as the adjustable parameter of this equation.

$\mathrm{d}$ Weighted mean value (the uncertainty was taken as the weighing factor). Uncertainty of the vaporization enthalpy is expressed as the standard uncertainties $(0.68$ level of confidence, $\mathrm{k}=1)$. Values highlighted in bold were recommended for thermochemical calculations.

\section{Table S5}

Compilation of data on auxiluar molar heat capacities $C_{\mathrm{p}, \mathrm{m}}^{\mathrm{o}}$ and differences $\Delta_{\mathrm{P}}^{\mathrm{g}} C_{\mathrm{p}, \mathrm{m}}^{\mathrm{o}}$ of cycloalkenes cyclo-alkenone, and cyclo-alkanones (in $\mathrm{J} \cdot \mathrm{K}^{-1} \cdot \mathrm{mol}^{-1}$ ) at $298.15 \mathrm{~K}$.

\begin{tabular}{llcc}
\hline compound & $C_{\mathrm{p}, \mathrm{m}}^{\mathrm{o}}(\mathrm{liq})^{\mathrm{a}}$ & $C_{\mathrm{p}, \mathrm{m}}^{\mathrm{o}}(\mathrm{g})$ & $-\Delta_{\mathrm{p}}^{\mathrm{g}} C_{\mathrm{p}, \mathrm{m}}^{\mathrm{o}}$ \\
\hline cyclopentene & 122.4 & $81.3[28]$ & $42.0^{\mathrm{c}}$ \\
cycloheptene & 173.1 & $124.1[28]$ & $49.0^{\mathrm{c}}$ \\
2-cyclohexene-1-one & 155.8 & & $45.0^{\mathrm{d}}$ \\
cycloheptanone & 189.9 & & 60.0 \\
cyclooctanone & 215.8 & & 66.7 \\
\hline
\end{tabular}

${ }^{a}$ Calculated according to the procedure developed by Chickos and Acree [17].

${ }^{\mathrm{b}}$ Calculated by the group-contribution procedure developed by Chickos et al. [17].

${ }^{c}$ Calculated as the difference column 3 and 4

$\mathrm{d}$ The primary vapor pressures from [21] and [22] were approximated by Clarke and Glew equation [29] and the $\Delta_{\mathrm{P}}^{\mathrm{g}} C_{\mathrm{p}, \mathrm{m}}^{\mathrm{o}}$-value was taken as the adjustable parameter of this equation, 


\section{Table S6}

Compilation of vaporization enthalpies, $\Delta_{\mathrm{P}}^{\mathrm{g}} H_{\mathrm{m}}^{\mathrm{o}}(298.15 \mathrm{~K})$, of cyclo-alkanes, cyclo-alkenes, cycloalkanones, and cyclo-alkenones and their Kovats's indices $\left(J_{x}\right)$ used for evaluation of experimental data.

\begin{tabular}{llcl}
\hline & & $J_{x}{ }^{\mathrm{a}}$ & $\Delta_{\mathrm{P}}^{\mathrm{g}} H_{\mathrm{m}}^{\mathrm{o}}(298 \mathrm{~K})_{\exp }{ }^{\mathrm{b}}$ \\
\cline { 3 - 4 } CAS & Compound & $566[30]$ & \multicolumn{1}{c}{$\mathrm{kJ} \cdot \mathrm{mol}^{-1}$} \\
\hline $287-92-3$ & cyclopentane & $669[30]$ & $33.1 \pm 0.1[31]$ \\
$110-82-7$ & cyclohexane & $800[30]$ & $38.5 \pm 0.2[32]$ \\
$291-64-5$ & cycloheptane & & \\
& & $558[30]$ & $28.6 \pm 0.2[$ Table S4] \\
$142-29-0$ & cyclopentene & $681[30]$ & $33.6 \pm 0.1[31]$ \\
$110-83-8$ & cyclohexene & $788[30]$ & $37.6 \pm 0.3[$ Table S4] \\
$628-92-2$ & cycloheptene & & \\
& & $633[33]$ & $38.2 \pm 0.4[23]$ \\
$1191-95-3$ & cyclobutanone & $752[38]$ & $42.1 \pm 0.2[34]$ \\
$120-92-3$ & cyclopentanone & $881[35]$ & $45.1 \pm 0.1[31]$ \\
$108-94-1$ & cyclohexanone & $987[36]$ & $50.9 \pm 0.3[$ Table S4] \\
$502-42-1$ & cycloheptanone & $1083[37]$ & $54.3 \pm 0.4[$ Table S4] \\
$502-49-8$ & cyclooctanone & & \\
& & $793[38]$ & - \\
$930-30-3$ & 2-cyclopentene-1-one & $920[35]$ & $47.9 \pm 0.1[$ Table S4] \\
$930-68-7$ & 2-cyclohexene-1-one & $1045[39]$ & - \\
$1121-66-0$ & 2-cycloheptene-1-one & &
\end{tabular}

${ }^{a}$ Kovats's indices, $J_{x}$, on the standard non-polar columns.

${ }^{\mathrm{b}}$ Reliable experimental data taken from the literature or evaluated in this work (see Table S4).

${ }^{\mathrm{c}}$ Calculated using Eq. (6) with the assessed standard uncertainty of $\pm 0.5 \mathrm{~kJ} \cdot \mathrm{mol}^{-1}$.

${ }^{\mathrm{d}}$ Difference between column 4 and 5 in this table.

Correlation of $\Delta \mathrm{P}_{\mathrm{m}}^{\mathrm{o}}(298.15 \mathrm{~K})$ with Kovats `s indices in order to get missing values for the structure-property correlations

Correlation Gas-Chromatographic (CGC) method is often used to validate the experimental enthalpies of vaporization or derive the unknown values [40]. This method is based on correlating the experimental $\Delta_{\mathrm{P}}^{\mathrm{g}} H_{\mathrm{m}}^{\mathrm{o}}(298.15 \mathrm{~K})$-values with their Kovats`s indices [41]. The $n$-alkanes are used as standards for the calculating the Kovats's retention index, $J_{\mathrm{x}}$, as follows [41]:

$$
J_{x}=\frac{\lg \left(t_{x}\right)-\lg \left(t_{N}\right)}{\lg \left(t_{N+1}\right)-\lg \left(t_{N}\right)} \times 100+100 N,
$$

where $x$ refers to the adjusted retention time $t_{x}$ of compound under determination; $N$ is the number of carbon atoms of the $n$-alkane eluting before, and $(N+1)$ is the number of carbon atoms of the $n$ alkane eluting after the peak of interest. According to the established GC procedure, all retention times are corrected for the "dead" retention time.

The literature data available on the retention indices for cyclic compounds were taken for correlation with the $\Delta_{\mathrm{P}}^{\mathrm{g}} H_{\mathrm{m}}^{\mathrm{o}}(298.15 \mathrm{~K})$-values evaluated in this work (see Table S4). The results of this correlation are given in the Table S7. 
Table S7

Cyclo-alkanones and cyclo-alkenones: correlation of vaporization enthalpies, $\Delta_{\mathrm{P}}^{\mathrm{g}} H_{\mathrm{m}}^{\mathrm{o}}(298.15 \mathrm{~K})$, with their Kovats's indices $\left(J_{x}\right)$

\begin{tabular}{lllccc}
\hline & & $J_{x}{ }^{\mathrm{a}}$ & \multicolumn{1}{c}{$\Delta_{\mathrm{P}}^{\mathrm{g}} H_{\mathrm{m}}^{\mathrm{o}}(298 \mathrm{~K})_{\exp }^{\mathrm{b}}$} & $\Delta_{\mathrm{P}}^{\mathrm{g}} H_{\mathrm{m}}^{\mathrm{o}}(298 \mathrm{~K})_{\mathrm{calc}^{\mathrm{b}}}$ & $\Delta^{1}$ \\
\cline { 3 - 6 } CAS & Compound & \multicolumn{2}{c}{$\mathrm{kJ} \cdot \mathrm{mol}^{-1}$} & $\mathrm{~kJ} \cdot \mathrm{mol}^{-1}$ & $\mathrm{~kJ} \cdot \mathrm{mol}^{-1}$ \\
\hline $1191-95-3$ & cyclobutanone & $633[33]$ & $38.2 \pm 0.4[23]$ & 37.7 & 0.5 \\
$120-92-3$ & cyclopentanone & $752[38]$ & $42.1 \pm 0.2[34]$ & 42.0 & 0.1 \\
$108-94-1$ & cyclohexanone & $881[35]$ & $45.1 \pm 0.1[31]$ & 46.6 & -1.5 \\
$502-42-1$ & cycloheptanone & $987[36]$ & $51.0 \pm 0.3[$ Table S6] & 50.4 & 0.6 \\
$502-49-8$ & cyclooctanone & $1083[37]$ & $54.3 \pm 0.5[$ Table S6] & 53.9 & 0.4 \\
& & & & & \\
$930-30-3$ & 2-cyclopentene-1-one & $793[38]$ & - & 43.5 & - \\
$930-68-7$ & 2-cyclohexene-1-one & $920[35]$ & $47.9 \pm 0.1[$ Table S6] & 48.0 & -0.1 \\
$1121-66-0$ & 2-cycloheptene-1-one & $1045[39]$ & - & 52.5 & - \\
\hline
\end{tabular}

${ }^{a}$ Kovats's indices, $J_{x}$, on the standard non-polar columns.

${ }^{\mathrm{b}}$ Calculated using Eq. (S3) with the assessed standard uncertainty of $\pm 0.5 \mathrm{~kJ} \cdot \mathrm{mol}^{-1}$.

${ }^{c}$ Difference between column 4 and 5 in this table.

It is known, that the $\Delta_{\mathrm{P}}^{\mathrm{g}} H_{\mathrm{m}}^{\mathrm{o}}(298.15 \mathrm{~K})$-values correlate linearly with Kovats`s indices in various homologous series of alkanes, alkylbenzenes, aliphatic ethers, alcohols, or in a series of structurally similar compounds [41]. As anticipated, the following linear correlation was obtained when the $\Delta_{\mathrm{p}}^{\mathrm{g}} H_{\mathrm{m}}^{\mathrm{o}}$ $(298.15 \mathrm{~K})$-values are correlated with $J_{x}$-values for the structurally parent set of amino-alcohols collected in Table S6:

$$
\Delta_{\mathrm{P}}^{\mathrm{g}} H_{\mathrm{m}}^{\mathrm{o}}(298.15 \mathrm{~K}) /\left(\mathrm{kJ} \cdot \mathrm{mol}^{-1}\right)=15.0+0.0359 \times J_{x} \quad \text { with }\left(R^{2}=0.9827\right)
$$

The vaporization enthalpies derived from the correlations with Kovats's indices (see Tables S7, column 5) are in a good agreement with those obtained from experiment. It can be seen from Table S7, that differences between experimental and calculated according to Eq. (S3) vaporization enthalpies are mostly below $1 \mathrm{~kJ} \cdot \mathrm{mol}^{-1}$. Hence, the uncertainties of enthalpies of vaporization which are estimated from the correlation the $\Delta_{\mathrm{P}}^{\mathrm{g}} H_{\mathrm{m}}^{\mathrm{o}}(298.15 \mathrm{~K})-J_{x}$ are evaluated with $\pm 0.5 \mathrm{~kJ} \cdot \mathrm{mol}^{-1}$.

\section{Combustion calorimetry [42,43]}

The liquid samples were encapsulated in small polyethylene ampoules. All weightings were performed by using a microbalance with $10^{-6} \mathrm{~g}$ resolution. The bomb was not pre-purged with $\mathrm{O}_{2}$. Test experiments with and without purging with $\mathrm{O}_{2}$ showed results consistent within the experimental uncertainty. Samples were ignited at $3.04 \mathrm{MPa}$ initial oxygen pressure adjusted to $298.15 \mathrm{~K}$. The combustion products were examined for carbon monoxide (Dräger tube) and unburned carbon, but neither was detected. The energy equivalent of the calorimeter $\varepsilon_{\text {calor }}$ was determined with a standard reference sample of benzoic acid (sample SRM 39j, NIST). Correction for nitric acid $\left(\mathrm{HNO}_{3}\right)$ formation was based on titration with $0.1 \mathrm{~mol} \cdot \mathrm{dm}^{-3} \mathrm{NaOH}(\mathrm{aq})$. Auxiliary data required for the reduction are presented in Table $\mathrm{S} 1$. 
Results for combustion experiments at $T=298.15 \mathrm{~K}\left(p^{\circ}=0.1 \mathrm{MPa}\right)$ with dihydro-levoglucosenone

\begin{tabular}{lccccc}
\hline$m$ (substance) $/ \mathrm{g}$ & 0.318283 & 0.347173 & 0.302908 & 0.338534 & 0.368357 \\
$m^{\prime}$ (cotton) $/ \mathrm{g}$ & 0.002175 & 0.002152 & 0.002385 & 0.002065 & 0.002199 \\
$m^{\prime \prime}($ polyethene) $/ \mathrm{g}$ & 0.247083 & 0.256114 & 0.239605 & 0.261949 & 0.249949 \\
$T_{\mathrm{i}} / \mathrm{K}$ & 298.14083 & 298.13783 & 298.14331 & 298.14168 & 298.14214 \\
$T_{f} / \mathrm{K}$ & 299.48064 & 299.55076 & 299.43975 & 299.55975 & 299.56929 \\
$\Delta T_{\mathrm{c}} / \mathrm{K}$ & 1.28069 & 1.35503 & 1.23334 & 1.36020 & 1.36957 \\
$\left(\varepsilon_{\text {calor }}\right) \cdot\left(-\Delta T_{\mathrm{c}}\right) / \mathrm{J}$ & -18955.6 & -20055.9 & -18254.8 & -20132.5 & -20270.7 \\
$\left(\varepsilon_{\text {cont }}\right) \cdot\left(-\Delta T_{\mathrm{c}}\right) / \mathrm{J}$ & -21.46 & -22.79 & -22.21 & -22.14 & -24.39 \\
$\Delta U_{\text {decomp }} \mathrm{HNO}_{3} / \mathrm{J}$ & 1.19 & 2.99 & 4.18 & 5.38 & 5.38 \\
$\Delta U_{\text {corr }} / \mathrm{J}$ & 7.82 & 8.50 & 7.82 & 8.28 & 9.02 \\
$-m^{\prime} \cdot \Delta_{\mathrm{c}} u^{\prime} / \mathrm{J}$ & 36.86 & 36.47 & 40.41 & 35.00 & 37.27 \\
$-m^{\prime \prime} \cdot \Delta_{\mathrm{c}} u^{\prime \prime} / \mathrm{J}$ & 11468.7 & 11887.9 & 11121.6 & 12158.8 & 11601.8 \\
$\Delta_{\mathrm{c}} u^{\circ}(\mathrm{liq}) /\left(\mathrm{J} \cdot \mathrm{g}^{-1}\right)$ & -23446.1 & -23454.7 & -23449.2 & -23475.3 & -23460.0 \\
\hline$-\Delta_{\mathrm{c}} u^{\circ}(\mathrm{liq}) /\left(\mathrm{J} \cdot \mathrm{g}^{-1}\right)$ & \multicolumn{5}{c}{$23457.1 \pm 5.1 \mathrm{~b}$} \\
\hline
\end{tabular}

${ }^{a}$ Results are referenced to $T=298.15 \mathrm{~K}\left(p^{\circ}=0.1 \mathrm{MPa}\right)$. The definition of the symbols assigned according to ref. [44] as follows: $m$ (substance), $m^{\prime}$ (cotton) and $m^{\prime \prime}$ (polyethylene) are, respectively, the mass of compound burnt, the mass of fuse (cotton) and auxiliary polyethylene used in each experiment, masses were corrected for buoyancy; $V($ bomb $)=0.32 \mathrm{dm}^{3}$ is the internal volume of the calorimetric bomb; $p^{\mathrm{i}}(\mathrm{gas})=3.04 \mathrm{MPa}$ is the initial oxygen pressure in the bomb; $m^{\mathrm{i}}\left(\mathrm{H}_{2} \mathrm{O}\right)$ $=1.00 \mathrm{~g}$ is the mass of water added to the bomb for dissolution of combustion gases; $\varepsilon_{\text {calor }}=14801.1 \pm 0.62 \mathrm{~J} \cdot \mathrm{K}^{-1}$, uncertainty for the energy equivalent is expressed as the standard uncertainty; $\Delta T^{\mathrm{c}}=T^{\mathrm{f}}-T^{\mathrm{i}}+\Delta T_{\text {corr }}$ is the corrected temperature rise from initial temperature $T^{\mathrm{i}}$ to final temperature $T^{\mathrm{f}}$, with the correction $\Delta T_{\text {corr }}$ for heat exchange during the experiment; $\varepsilon_{\text {cont }}$ is the energy equivalents of the bomb contents in their initial $\varepsilon_{\text {cont }}^{i}$ and final states $\varepsilon_{\text {cont }}^{\mathrm{f}}$, the contribution for the bomb content is calculated with $\left(\varepsilon_{\text {cont }}\right) \cdot\left(-\Delta T_{\mathrm{c}}\right)=\left(\varepsilon_{\text {cont }}\right) \cdot\left(T^{\mathrm{i}}-298.15\right)+\left(\varepsilon_{\text {cont }}^{\mathrm{f}}\right) \cdot\left(298.15-T^{\mathrm{f}}+\Delta T_{\text {corr. }}\right) \cdot \Delta U_{\text {decomp }} \mathrm{HNO}_{3}$ is the energy correction for the nitric acid formation. $\Delta U_{\text {corr }}$ is the correction to standard states. Auxiliary data are given in Table S1.

${ }^{b}$ Uncertainty of combustion energy is expressed as standard deviation of the mean [45]. 
Table S9

Results for combustion experiments at $T=298.15 \mathrm{~K}\left(p^{\circ}=0.1 \mathrm{MPa}\right)$ with levoglucosenone ${ }^{\text {a }}$

\begin{tabular}{lccccc}
\hline$m$ (substance) $/ \mathrm{g}$ & 0.273185 & 0.192696 & 0.201430 & 0.229295 & 0.185123 \\
$m^{\prime}$ (cotton) $/ \mathrm{g}$ & 0.002723 & 0.002345 & 0.002321 & 0.002396 & 0.002173 \\
$m^{\prime \prime}$ (polyethene) $/ \mathrm{g}$ & 0.220439 & 0.223720 & 0.233758 & 0.246035 & 0.266325 \\
$T_{\mathrm{i}} / \mathrm{K}$ & 298.12411 & 298.13226 & 298.12033 & 298.12564 & 298.12123 \\
$T_{f} / \mathrm{K}$ & 299.29217 & 299.19316 & 299.22268 & 299.30697 & 299.29839 \\
$\Delta T_{\mathrm{c}} / \mathrm{K}$ & 1.10941 & 0.99687 & 1.04126 & 1.12231 & 1.11851 \\
$\left(\varepsilon_{\text {calor }}\right) \cdot\left(-\Delta T_{\mathrm{c}}\right) / \mathrm{J}$ & -16417.5 & -14752.1 & -15408.9 & -16608.4 & -16552.2 \\
$\left(\varepsilon_{\text {cont }}\right) \cdot\left(-\Delta T_{\mathrm{c}}\right) / \mathrm{J}$ & -17.62 & -15.97 & -17.28 & -17.84 & -17.65 \\
$\Delta U_{\text {decomp }} \mathrm{HNO}_{3} / \mathrm{J}$ & 5.38 & 4.18 & 3.58 & 4.18 & 4.18 \\
$\Delta U_{\text {corr }} / \mathrm{J}$ & 7.03 & 5.90 & 6.26 & 6.72 & 6.31 \\
$-m^{\prime} \cdot \Delta_{\mathrm{c}} u^{\prime} / \mathrm{J}$ & 46.14 & 39.74 & 39.33 & 40.60 & 36.82 \\
$-m^{\prime \prime} \cdot \Delta_{\mathrm{c}} u^{\prime \prime} / \mathrm{J}$ & 10232.0 & 10384.3 & 10850.2 & 11420.1 & 12361.9 \\
$\Delta_{\mathrm{c}} u^{\circ}(\mathrm{liq}) /\left(\mathrm{J} \cdot \mathrm{g}^{-1}\right)$ & -22492.3 & -22491.1 & -22473.6 & -22480.4 & -22474.9 \\
\hline$-\Delta_{\mathrm{c}} u^{\circ}(\mathrm{liq}) /\left(\mathrm{J} \cdot \mathrm{g}^{-1}\right)$ & \multicolumn{5}{c}{$22482.5 \pm 3.9 \mathrm{~b}$} \\
\hline
\end{tabular}

${ }^{a}$ The value of the energy equivalent of the calorimeter: $\varepsilon_{\text {calor }}=14798.4 \pm 0.9 \mathrm{~J} \cdot \mathrm{K}^{-1}$

${ }^{b}$ Uncertainty of combustion energy is expressed as standard deviation of the mean [45].

\section{Quantum-chemical calculations}

The structure of the most stable conformers was found in the ADF program [46] with the methods M06L/TZ2P and M06/QZ4P based on the Slater Cartesian functions. The convergence of energy was better than $10^{-6}$ a.u. and for the gradients (forces) not more than $10^{-6}$ a.u. $/ \AA$. The fundamental harmonic frequencies of methoxy-substituted phenols and benzaldehydes were obtained using M06L/TZ2P and corrected to anharmonic using a cubic polynomial. For this we found the harmonic frequencies of benzoquinone and methyl-benzoquinone [47] according to the M06L/TZ2P method, which contain a similar amount of atoms and well-established spectra, and the parameters of the third degree approximation polynomial were calculated based on the total set of frequencies available for the two molecules compared to the experimental values.

The harmonic and anharmonic frequencies of the most stable conformers were used to determine the zero point of energy and temperature contributions to enthalpy for M06/QZ4P in the "rigid rotator - anharmonic oscillator" (RRAO) approximation. Enthalpies $H_{298}$ of the most stable conformers for each isomer were calculated by using the G3MP2 [48], G4MP2 [49], and G4 [50] methods. The $H_{298}$-values have been converted to the standard molar enthalpies of formation $\Delta_{\mathrm{f}} H_{\mathrm{m}}^{\mathrm{o}}(\mathrm{g}$, $298.15 \mathrm{~K})_{\text {theor }}$ using the atomization $(\mathrm{AT})$ reaction:

$$
C_{\mathrm{m}} H_{\mathrm{n}} O_{\mathrm{k}}=\mathrm{m} \times \mathrm{C}+\mathrm{n} \times H+\mathrm{k} \times O
$$




\section{Table S10}

Experimental gas-phase enthalpies of formation, $\Delta_{\mathrm{f}} H_{m}^{\mathrm{o}}(\mathrm{g})_{\text {exp }}$, used for correlation with the G3MP2theoretical results, $\Delta_{\mathrm{f}} H_{m}^{\mathrm{o}}(\mathrm{g})_{\mathrm{AT}}$, calculated according to the atomization procedure, at $298.15 \mathrm{~K}$ (in $\left.\mathrm{kJ} \cdot \mathrm{mol}^{-1}\right)$

\begin{tabular}{llrrrr}
\hline CAS & Compound & $\Delta_{\mathrm{f}} H_{m}^{\mathrm{o}}(\mathrm{g})_{\mathrm{AT}}{ }^{\mathrm{a}}$ & \multicolumn{1}{c}{$\Delta_{\mathrm{f}} H_{m}^{\mathrm{o}}(\mathrm{g})_{\exp }$} & $\Delta_{\mathrm{f}} H_{m}^{\mathrm{o}}(\mathrm{g})_{\text {ATcorr }}{ }^{\mathrm{b}}$ & \multicolumn{1}{c}{$\Delta^{\mathrm{c}}$} \\
\hline $616-38-6$ & dimethyl carbonate & -569.5 & $-570.7 \pm 0.6[51]$ & -569.8 & -0.9 \\
$105-58-8$ & diethyl carbonate & -638.4 & $-637.9 \pm 0.9[51]$ & -639.1 & 1.2 \\
$96-49-1$ & ethylene carbonate & -508.4 & $-510.7 \pm 0.9[51]$ & -508.4 & -2.3 \\
$108-32-7$ & propylene carbonate & -552.3 & $-553.9 \pm 0.8[51]$ & -552.6 & -1.3 \\
$4437-85-8$ & butylene carbonate & -573.7 & $-576.7 \pm 1.2[51]$ & -574.1 & -2.6 \\
$994-05-8$ & tert-amyl methyl ether & -305.8 & $-301.5 \pm 1.7[52]$ & -304.8 & 3.3 \\
$498-07-7$ & levoglucosan & -831.2 & $-830.4 \pm 1.7[51]$ & $\mathbf{- 8 3 2 . 9}$ & 2.5 \\
$53716-82-8$ & cyrene & -437.4 & & $\mathbf{- 4 3 7 . 1}$ & \\
$37112-31-5$ & levoglucosenone & -318.8 & & $\mathbf{- 3 1 7 . 9}$ & \\
\hline
\end{tabular}

${ }^{a}$ Calculated by the G3MP2 method according to the standard atomization procedure. (The expanded uncertainty assessed to be $\pm 4.1 \mathrm{~kJ} \cdot \mathrm{mol}^{-1}$ ) [48].

${ }^{\mathrm{b}}$ Results from atomization reactions were corrected with help of the following equation:

$\Delta_{\mathrm{f}} H_{\mathrm{m}}^{\mathrm{o}}(\mathrm{g})_{\text {theor }} / \mathrm{kJ} \cdot \mathrm{mol}^{-1}=1.0050 \times \Delta_{\mathrm{f}} H_{\mathrm{m}}^{\mathrm{o}}(\mathrm{g}, \mathrm{AT})+2.5$ with $R^{2}=0.9998$

${ }^{\mathrm{c}}$ Difference between column 4 and 5.

\section{Table S11}

Experimental gas-phase enthalpies of formation, $\Delta_{\mathrm{f}} H_{m}^{\mathrm{o}}(\mathrm{g})_{\text {exp }}$, used for correlation with the G4MP2theoretical results, $\Delta_{\mathrm{f}} H_{m}^{\mathrm{o}}(\mathrm{g})_{\mathrm{AT}}$, calculated according to the atomization procedure, at $298.15 \mathrm{~K}$ (in $\left.\mathrm{kJ} \cdot \mathrm{mol}^{-1}\right)$

\begin{tabular}{llrrrr}
\hline CAS & Compound & $\Delta_{\mathrm{f}} H_{m}^{\mathrm{o}}(\mathrm{g})_{\mathrm{AT}}{ }^{\mathrm{a}}$ & \multicolumn{1}{c}{$\Delta_{\mathrm{f}} H_{m}^{\mathrm{o}}(\mathrm{g})_{\exp }$} & $\Delta_{\mathrm{f}} H_{m}^{\mathrm{o}}(\mathrm{g})_{\mathrm{ATcorr}}{ }^{\mathrm{b}}$ & $\Delta^{\mathrm{c}}$ \\
\hline $109-87-5$ & dimethoxy methane & -349.3 & $-348.2 \pm 0.8[52]$ & -351.0 & 2.8 \\
$534-15-6$ & 1,1-dimethoxy ethane & -388.5 & $-389.7 \pm 0.8[53]$ & -390.3 & 0.6 \\
$110-71-4$ & 1,2-dimethoxy ethane & -342.8 & $-342.8 \pm 0.7[54]$ & -344.5 & 1.7 \\
$126-84-1$ & 2,2-diethoxy-propane & -496.4 & $-495.3 \pm 0.2[52]$ & -498.3 & 3.0 \\
$149-73-5$ & trimethoxy methane & -529.8 & $-530.8 \pm 2.3[52]$ & -531.8 & 1.0 \\
$122-51-0$ & triethoxy methane & -623.7 & $-630.6 \pm 1.5[52]$ & -625.8 & -4.8 \\
$1445-45-0$ & 1,1,1-trimethoxy ethane & -568.1 & $-570.8 \pm 1.6[52]$ & -570.2 & -0.6 \\
$24823-81-2$ & 1,1,1-trimethoxy propane & -589.9 & $-589.9 \pm 1.9[52]$ & -592.0 & 2.1 \\
$142-96-1$ & butyl methyl ether & -257.3 & $-258.3 \pm 1.2[52]$ & -258.9 & 0.6 \\
$111-43-3$ & dipropyl ether & -292.7 & $-293.1 \pm 0.9[52]$ & -291.9 & -1.2 \\
$142-96-1$ & dibutyl ether & -330.3 & $-332.9 \pm 1.0[52]$ & -332.0 & -0.9 \\
$1850-14-2$ & tetra-methoxy methane & -726.1 & $-727.3 \pm 1.5[52]$ & -728.4 & 1.1 \\
$109-86-4$ & 2-methoxyethanol & -369.8 & $-376.8 \pm 1.6[55]$ & -371.6 & -5.2 \\
$53716-82-8$ & cyrene & -435.2 & & -437.1 & \\
$37112-31-5$ & levuglucosenone & -317.8 & & -319.5 & \\
\hline
\end{tabular}

${ }^{a}$ Calculated by the G4MP2 method according to the standard atomization procedure. (The expanded uncertainty assessed to be $\pm 3.3 \mathrm{~kJ} \cdot \mathrm{mol}^{-1}$ ) [49].

${ }^{\mathrm{c}}$ Results from atomization reactions were corrected with help of following equation:

$\Delta_{\mathrm{f}} H_{\mathrm{m}}^{\mathrm{o}}(\mathrm{g})_{\text {theor }} / \mathrm{kJ} \cdot \mathrm{mol}^{-1}=1.0015 \times \Delta_{\mathrm{f}} H_{\mathrm{m}}^{\mathrm{o}}(\mathrm{g}, \mathrm{AT})-1.2 \quad$ with $R^{2}=0.9998$

${ }^{\mathrm{d}}$ Difference between column 4 and 5 . 


\section{Table S12}

Experimental gas-phase enthalpies of formation, $\Delta_{\mathrm{f}} H_{m}^{\mathrm{o}}(\mathrm{g})_{\exp }$, used for correlation with the G4theoretical results, $\Delta_{\mathrm{f}} H_{m}^{\mathrm{o}}(\mathrm{g})_{\mathrm{AT}}$, calculated according to the atomization procedure, at $298.15 \mathrm{~K}$ (in $\left.\mathrm{kJ} \cdot \mathrm{mol}^{-1}\right)$

\begin{tabular}{|c|c|c|c|c|c|}
\hline CAS & compound & $\Delta_{\mathrm{f}} H_{m}^{\mathrm{o}}(\mathrm{g})_{\mathrm{AT}}{ }^{\mathrm{a}}$ & $\Delta_{\mathrm{f}} H_{m}^{\mathrm{o}}(\mathrm{g})_{\exp }$ & $\Delta_{\mathrm{f}} H_{m}^{\mathrm{o}}(\mathrm{g})_{\mathrm{ATcorr}}^{\mathrm{b}}$ & $\Delta^{\mathrm{c}}$ \\
\hline $109-87-5$ & dimethoxy methane & -353.9 & $-348.2 \pm 0.8[52]$ & -350.7 & -2.5 \\
\hline $534-15-6$ & 1,1-dimethoxy ethane & -393.5 & $-389.7 \pm 0.8[53]$ & -390.1 & -0.4 \\
\hline $110-71-4$ & 1,2-dimethoxy ethane & -347.2 & $-342.8 \pm 0.7[54]$ & -344.0 & -1.2 \\
\hline $126-84-1$ & 2,2-diethoxy-propane & -502.5 & $-495.3 \pm 0.2[52]$ & -498.7 & -3.4 \\
\hline $149-73-5$ & tri-methoxy methane & -537.3 & $-530.8 \pm 2.3[52]$ & -533.4 & -2.6 \\
\hline $122-51-0$ & tri-ethoxy methane & -631.9 & $-630.6 \pm 1.5[52]$ & -627.7 & 2.9 \\
\hline $1445-45-0$ & 1,1,1-trimethoxy ethane & -576.4 & $-570.8 \pm 1.6[52]$ & -572.4 & -1.6 \\
\hline $24823-81-2$ & 1,1,1-trimethoxy propane & -598.6 & $-589.9 \pm 1.9[52]$ & -594.5 & -4.6 \\
\hline $142-96-1$ & butyl methyl ether & -259.5 & $-258.3 \pm 1.2[52]$ & -256.6 & 1.7 \\
\hline $111-43-3$ & dipropyl ether & -292.7 & $-293.1 \pm 0.9[52]$ & -289.7 & 3.4 \\
\hline $142-96-1$ & dibutyl ether & -332.5 & $-332.9 \pm 1.0[52]$ & -329.3 & 3.6 \\
\hline $100-66-3$ & methoxy benzene & -71.3 & $-70.7 \pm 1.4[56]$ & -69.1 & 1.6 \\
\hline $103-73-1$ & ethoxy benzene & -105.8 & $-101.6 \pm 1.2[53]$ & -103.4 & -1.8 \\
\hline $578-58-5$ & 2-methyl-methoxybenzene & -107.7 & $-106.6 \pm 1.6[57]$ & -105.3 & 1.3 \\
\hline $104-93-8$ & 4-methyl-methoxybenzene & -103.1 & $-99.3 \pm 2.0[57]$ & -100.7 & -1.4 \\
\hline $994-05-8$ & tert-amyl ether & -304.3 & $-301.5 \pm 1.7[52]$ & -301.2 & 0.3 \\
\hline $8021-39-4$ & 2-methoxy-phenol & -251.1 & $-247.3 \pm 1.8[58]$ & -248.2 & -0.9 \\
\hline $91-16-7$ & 1,2-dimethoxybenzene & -211.2 & $-206.0 \pm 3.1[58]$ & -208.5 & -2.5 \\
\hline $123-91-1$ & 1,4-dioxane & -317.8 & $-315.3 \pm 0.8[53]$ & -314.7 & 0.6 \\
\hline $110-88-3$ & 1,3,5-trioxane & -471.0 & $-465.9 \pm 0.4[53]$ & -467.4 & -1.5 \\
\hline $108-20-3$ & di-isopropyl ether & -321.5 & $-319.5 \pm 1.4[52]$ & -318.4 & 1.1 \\
\hline $616-38-6$ & di-methyl carbonate & -573.6 & $-570.7 \pm 0.6[51]$ & -569.6 & 1.1 \\
\hline $105-58-8$ & di-ethyl carbonate & -640.6 & $-637.9 \pm 0.9[51]$ & -636.4 & 1.5 \\
\hline $96-49-1$ & ethylene carbonate & -512.5 & $-510.7 \pm 0.9[51]$ & -508.7 & 2.0 \\
\hline $108-32-7$ & propylene carbonate & -556 & $-553.9 \pm 0.8[51]$ & -552.1 & 1.8 \\
\hline $4437-85-8$ & butylene carbonate & -578.3 & $-576.7 \pm 1.2[51]$ & -574.3 & 2.4 \\
\hline $53716-82-8$ & cyrene & -321.6 & & -318.5 & \\
\hline $37112-31-5$ & levoglucosenone & -440.5 & & -437.0 & \\
\hline $498-07-7$ & levoglucosan & -836 & & -831.1 & \\
\hline
\end{tabular}

${ }^{a}$ Calculated by the G4 method according to the standard atomization procedure. (The expanded uncertainty assessed to be $\pm 3.5 \mathrm{~kJ} \cdot \mathrm{mol}^{-1}$ ) [50].

${ }^{\mathrm{b}}$ Results from atomization reactions were corrected with help of following equation:

$\Delta_{\mathrm{f}} H_{\mathrm{m}}^{\mathrm{o}}(\mathrm{g})_{\text {theor }} / \mathrm{kJ} \cdot \mathrm{mol}^{-1}=0.9965 \times \Delta_{\mathrm{f}} H_{\mathrm{m}}^{\mathrm{o}}(\mathrm{g}, \mathrm{AT})+2.0 \quad$ with $R^{2}=0.9998$

${ }^{\mathrm{c}}$ Difference between column 4 and 5 . 


\section{References for Supporting Information}

[1] Baird Z.S.; Uusi-Kyyny P.; Pokki J.-P.; Pedegert E.; Alopaeus V. Vapor Pressures, Densities, and PC-SAFT Parameters for 11 Bio-compounds. Int. J. of Thermophysics. 2019, 40, 102.

[2] Verevkin S.P. Thermochemistry of Phenols: Quantification of the Ortho-, Para-, and Metainteractions in Tert-alkyl Substituted Phenols, J. Chem. Thermodyn. 1999, 31, 559.

[3] Emel yanenko V.N.; Zaitsau D.H.; Shoifet E.; Meurer F.; Verevkin S.P.; Schick C.; Held C. Benchmark thermochemistry for biologically relevant adenine and cytosine. A combined experimental and theoretical study. J. Phys. Chem. A. 2015, 119, 9680.

[4] Kulikov D.; Verevkin S.P.; Heintz A. Enthalpies of vaporization of a series of linear aliphatic alcohols. Experimental measurements and application of the ERAS-model for their prediction. Fluid Phase Equilib. 2001, 192, 187.

[5] Verevkin S.P.; Emel'yanenko V.N. Transpiration method: Vapour pressures and enthalpies of vaporization of some low-boiling esters. Fluid Phase Equilib. 2008, 266, 64.

[6] Shafizadeh F.; McGinnis G.D.; Philpot C.W.; Susott R.A. Solid-state transition of 1,6-anhydrob-D-glucopyranose. Carbohydr. Res. 1970, 13, 184.

[7] Shafizadeh F. Thermal behavior of carbohydrates. J. Polym. Sci. C: Polym. Symp. 1971, 36, 21.

[8] Shafizadehm F.; McGinnes G. D.; Susott R. A.; Philpot C. W. Thermodynamic properties of 1,6anhydrohexopyranose crystals. Carbohydr. Res. 1970, 15, 165.

[9] Suuberg E. M.; Milosavljevic I.; Oja V. Two-Regime Global Kinetics of Cellulose Pyrolysis: The Role of Tar Evaporation. 26th Symposium (International) on Combustion; The Combustion Institute: Pittsburgh, PA, 1996, 1515.

[10] Oja V.; Suuberg E.M. Development of a Nonisothermal Knudsen Effusion Method and Application to PAH and Cellulose Tar Vapor Pressure Measurement. Anal. Chem. 1997, 69, 4619.

[11] Oja V.; Suuberg E.M. Vapor Pressures and Enthalpies of Sublimation of D-Glucose, D-Xylose, Cellobiose, and Levoglucosan. J. Chem. Eng. Data. 1999, 44, 26.

[12] Booth A.M.; Montague W.J.; Barley M.H.; Topping D.O.; McFiggans G.; Garforth A.; Percival C. J. Solid state and sub-cooled liquid vapour pressures of cyclic aliphatic dicarboxylic acids. Atmos. Chem. Phys. 2011, 11, 655.

[13] Rocha I.M.; Galvao T.L.P.; Sapei E.; Ribeiro da Silva M.D.M.C.; Ribeiro da Silva M.A.V. Levoglucosan: A calorimetric, thermodynamic, spectroscopic, and computational investigation. $J$. Chem. Eng. Data. 2013, 58, 1813.

[14] Kabo G.J.; Paulechka Y.U.; Voitkevich O.V. Blokhin A.V.; Stepurko E.N.; Kohut S.V.; Voznyi Y.V. Experimental and theoretical study of thermodynamic properties of levoglucosan. J. Chem. Thermodynamics. 2015, 85, 101.

[15] Tombari E.; Johari G. P. Structural fluctuations and orientational glass of levoglucosan-High stability against ordering and absence of structural glass. J. Chem. Phys. 2015, 142, 104501.

[16] Kaminska E.; Madejczyk O.; Tarnacka M.; Jurkiewicz K.; Wolnica K.; Smiszek-Lindert W.E.; Kaminski K.; Paluch M. Anhydrosaccharides-A new class of the fragile plastic crystals. J. Chem. Phys. 2018, 148, 074501.

[17] Acree W. Phase Transition Enthalpy Measurements of Organic and Organometallic Compounds. Sublimation, Vaporization and Fusion Enthalpies From 1880 to 2015. Part 1. C1 - C10. J. Phys. Chem. Ref. Data. 2016, 45, 033101.

[18] Gobble C.; Chickos J.; Verevkin S. P. Vapor pressures and Vaporization Enthalpies of a Series of Dialkyl Phthalates by Correlation Gas Chromatography. J. Chem. End Data. 2014, 59, 1353.

[19] Forziati A.F.; Camin D.L.; Rossini F.D. Density, refractive index, boiling point, and vapor pressure of eight monoolefin (1-alkene), six pentadiene, and two cyclomonoolefin hydrocarbons. $J$. Res. Natl. Bur. Stan. 1950, 45, 406.

[20] Lister M.W. Heats of organic reactions. X. Heats of bromination of cyclic olefins. J. Am. Chem. Soc. 1941, 63, 143.

[21] Steele W.V.; Chirico R.D.; Knipmeyer S.E.; Nguyen A. Vapor Pressure, Heat Capacity, and Density along the Saturation Line, Measurements for Cyclohexanol, 2-Cyclohexen-1-one, 1,2- 
Dichloropropane, 1,4-Di- tert -butylbenzene, ( \pm )-2-Ethylhexanoic Acid, 2-(Methylamino)ethanol, Perfluoro- n -heptane, and Sulfolane. J. Chem. Eng. Data. 1997, 42, 1021.

[22] Palczewska-Tulinska M.; Oracz P. Vapor Pressures of Hexanal, 2-Methylcyclohexanone, and 2Cyclohexen-1-one. J. Chem. Eng. Data. 2006, 51, 639.

[23] Wolf G. Thermochemische Untersuchungen an cyclischen Ketonen. Helv. Chim. Acta. 1972, 55, 1446.

[24] Meyer E.F.; Hotz C.A. Cohesive energies in polar organic liquids. 3. Cyclic ketones. J. Chem. Eng. Data. 1976, 21, 274.

[25] Chickos J.S.; Hosseini S.; Hesse D.G. Determination of vaporization enthalpies of simple organic molecules by correlations of changes in gas chromatographic net retention times. Thermochimica Acta. 1995, 249, 41.

[26] Verevkin S.P.; Sazonova A.Y.; Emel'yanenko V.N.; Zaitsau D.H. Varfolomeev M.A.; Solomonov B.N.; Zherikova K. V. Thermochemistry of halogen-substituted methylbenzenes. $J$. Chem. Eng. Data. 2015, 60, 89.

[27] Emel'yanenko V.N.; Verevkin S.P. Benchmark thermodynamic properties of 1,3-propanediol: Comprehensive experimental and theoretical study. J. Chem. Thermodyn. 2015, 85, 111.

[28] Dorofeeva O.V. Thermodynamic properties of twenty-one monocyclic hydrocarbons, J. Phys. Chem. Ref. Data. 1986, 15, 437.

[29] Clarke E. C. W.; Glew D. N. Evaluation of thermodynamic functions from equilibrium constants. Trans. Faraday Soc. 1966, 62, 539.

[30] Bredael P. Retention indices of hydrocarbons on SE-30. J. Hi. Res. Chromatogr. Chromatogr. Comm. 1982, 5, 325.

[31] Majer V.; Svoboda V. Enthalpies of Vaporization of Organic Compounds: A Critical Review and Data Compilation, Blackwell Scientific Publications, Oxford, 1985.

[32] Finke H.L.; Scott D.W.; Gross M.E.; Messerly J.F.; Waddington G. Cycloheptane, Cyclooctane and 1,3,5-Cycloheptatriene. Low Temperature Thermal Properties, Vapor Pressure and Derived Chemical Thermodynamic Properties. J. Am. Chem. Soc. 1956, 78, 5469.

[33] Zenkevich I.G. Informational Maitenance of Gas Chromatographic Identification of Organic Compounds in Ecoanalytical Investigations. Z. Anal. Chem. 1996, 51, 1140.

[34] Dikii V.V.; Kabo G.Ya. Thermodynamic properties and pseudorotation of cyclopentanone. Dokl. Akad. Nauk SSSR. 1991, 35, 158.

[35] Buchman O.; Cao G.-Y.; Peng C.T. Structure assignment by retention index in gas-liquid radiochromatography of substituted cyclohexenes. J. Chromatogr. 1984, 312, 75-.

[36] Zenkevich I.G. Non-Traditional Criteria for Gas-Chromatographic and Chromato-MassSpectrometric Identification of Organic Compounds. Zh. Anal. Khim. 1998, 53, 828.

[37] Lebrón-Aguilar R.; Quintanilla-López J.E.; Tello A.M.; Santiuste J.M. Isothermal retention indices on poly (3,3,3-trifluoropropylmethylsiloxane) stationary phases. J. Chromatogr. A. 2007, $1160,276$.

[38] Takeoka G.; Perrino C. Jr.; Buttery R. Volatile constituents of used frying oils. J. Agric. Food Chem. 1996, 44, 654.

[39] Warthen J.D.; Lee C.-J.; Jang E.B.; Lance D.O.; McInnis. Volatile, potential attractants from ripe coffee fruit for female Mediterranean D.R. fruit fly. J. Chem. Ecol. 1997, 23, 1891.

[40] Verevkin S.P. Vapour Pressures and Enthalpies of Vaporization of a Series of the Linear nalkyl-benzenes. J. Chem. Thermodyn. 2006, 38, 1111.

[41] Kovats E. Gas-chromatographische Charakterisierung Organischer Verbindungen. Teil 1: Retentionsindices Aliphatischer Halogenide, Alkohole, Aldehyde und Ketone. Helv. Chim. Acta. 1958, 41, 1915.

[42] Verevkin S.P.; Schick C. Substituent effects on the benzene ring. Determination of the intramolecular interactions of substituents in tert-alkyl substituted catechols from thermochemical measurements. J. Chem. Eng. Data. 2000, 45, 946. 
[43] Emel yanenko V.N.; Verevkin S.P.; Heintz A. The gaseous enthalpy of formation of the ionic liquid 1-butyl-3-methyl-imidazolium dicyanoamide from combustion calorimetry, vapor pressure measurements, and ab initio calculations. J. Amer. Chem. Soc. 2007, 129, 3930.

[44] Hubbard W.N.; Scott D.W.; Waddington G. Standard States and Corrections for Combustions in a Bomb at Constant Volume, in: F.D. Rossini (ed.), Experimental Thermochemistry. Interscience Publishers: New York, 1956.

[45] Olofsson G. Assignment of Uncertainties, in: S. Sunner, M. Månsson (Eds.), Combustion Calorimetry: Experimental Chemical Thermodynamics. Pergamon: New York, 1979.

[46] te Velde G.; Bickelhaupt F.M.; van Gisbergen S.J.A.; Fonseca Guerra C.; Baerends E. J.; Snijders J. G.; Ziegler T. Chemistry with ADF. J. Comp. Chem. 2001, 22, 931.

[47] Emel'yanenko V.N.; Varfolomeev M.A.; Novikov V.B.; Turovtsev V.V.; Orlov Y.D. Thermodynamic Properties of 1,4-Benzoquinones in Gaseous and Condensed Phases: Experimental and Theoretical Studies. J. Chem. Eng. Data. 2017, 62, 2413.

[48] Curtiss L.A.; Redfern P.C.; Raghavachari K.; Rassolov V. Pople J.A. Gaussian-3 Theory Using Reduced Möller-Plesset order. J. Chem. Phys. 1999, 110, 4703.

[49] Narayanan B.; Redfern P.C.; Assary R.S.; Curtiss L.A. Accurate quantum chemical energies for 133000 organic molecules. Chem. Sci. 2019, 10, 7449.

[50] Curtiss L.A.; Redfern P.C.; Raghavachari K. Gaussian-4 Theory. J. Chem. Phys. 2007, 126, 84108 .

[51] Verevkin S.P.; Emel'yanenko V.N.; Kozlova S.A. Organic Carbonates: Experiment and ab Initio Calculations for Prediction of Thermochemical Properties. J. Phys. Chem. A. 2008, 112, 10667.

[52] Verevkin S.P. Improved Benson Increments for the Estimation of Standard Enthalpies of Formation and Enthalpies of Vaporization of Alkyl Ethers, Acetals, Ketals, and Ortho Esters. $J$. Chem. Eng. Data. 2002, 47, 1071.

[53] Pedley J.B.; Naylor R.D.; Kirby S.P. Thermochemical Data of Organic Compounds, Chapman and Hall. New York, 1986.

[54] Steele W.V.; Chirico R.D.; Knipmeyer S.E.; Nguyen A.; Smith N.K. Thermodynamic properties and ideal-gas enthalpies of formation for butyl vinyl ether, 1,2-dimethoxyethane, methyl glycolate, bicyclo[2.2.1]hept-2-ene, 5-vinylbicyclo[2.2.1] hept-2-ene, trans-azobenzene, butyl acrylate, di-tertbutyl ether, and hexane-1,6-diol. J. Chem. Eng. Data. 1996, 41, 1285.

[55] Steele W.V.; Chirico R.D.; Hossenlopp I.A.; Knipmeyer S.E.; Nguyen A.; Smith N.K. DIPPR project 871 . Determination of ideal-gas enthalpies of formation for key compounds. The 1990 project results, Experimental Results for DIPPR 1990-91 Projects on Phase Equilibria and Pure Component Properties. 1994, 2, 188.

[56] Simões R.G.; Agapito F.; Diogo H.P.; Minas da Piedade M. E. The Enthalpy of Formation of Anisole: Implications for the Controversy on the O-H Bond Dissociation Enthalpy in Phenol. J. Phys. Chem. A. 2014, 118, 11026.

[57] Emel yanenko V.N.; Zaitseva K.V.; Agapito F.; Martinho Simões J.A.; Verevkin S.P. Benchmark Thermodynamic Properties of Methyl-Anisoles: Experimental and Theoretical Study. $J$. Chem. Thermodyn. 2015, 85, 155.

[58] Verevkin S.; Konnova M.; Turovtsev V.; Riabchunova A.; Pimerzin A. Weaving a Network of Reliable Thermochemistry around Lignin Building Blocks: Methoxy-Phenols and MethoxyBenzaldehydes. Ind. Eng. Chem. Res. 2020, 59, 22626. 